This is the final accepted version of the article Mérö TO, Žuljević A, Varga K, Lengyel S (2015) Habitat use and nesting success of the Great Reed Warbler (Acrocephalus arundinaceus) in different reed habitats in Serbia. The Wilson Journal of Ornithology 127(3):477-485. doi: http://dx.doi.org/10.1676/13-200.1

The final published version can be found at

http://www.bioone.org/doi/10.1676/13-200.1

\title{
HABITAT USE AND NESTING SUCCESS OF THE GREAT REED WARBLER (ACROCEPHALUS ARUNDINACEUS) IN DIFFERENT REED HABITATS IN \\ SERBIA
}

THOMAS OLIVER MÉRÖ, ${ }^{1}$ ANTUN ŽULJEVIĆ, ${ }^{1}$ KATALIN VARGA, ${ }^{2}$ AND SZABOLCS LENGYEL ${ }^{3}$

\footnotetext{
${ }^{1}$ Nature Protection and Study Society - NATURA, Milana Rakića 20, 25000 Sombor, Serbia, e-mail: thomas.oliver.mero@gmail.com
}

${ }^{2}$ Institute of Biosciences, Technische Universität Bergakademie Freiberg, Leipziger Str. 29, DE-09599 Freiberg, Germany, e-mail: varg.kata@gmail.com

${ }^{3}$ Department of Tisza River Research, Danube Research Institute, Centre for Ecological Research, Hungarian Academy of Sciences, Bem tér 18/c, H-4026 Debrecen, Hungary, email: lengyel.szabolcs@okologia.mta.hu

${ }^{4}$ Corresponding author; e-mail: thomas.oliver.mero@gmail.com 
1 ABSTRACT.---We surveyed five reed habitats (mining pond, sand pit, large canal, small

2 canal and lowland river) in north-western Vojvodina (Serbia) between 2009-2011 to study

3 habitat use and to estimate nest success in an understudied region of the breeding range of the

4 Great Reed Warbler (Acrocephalus arundinaceus). Data from 174 nests showed that habitat

5 use differed considerably between the habitat types, but was not related to the area of the

6 study site or the reed bed. Higher-than-expected numbers of nests along the small canal and

7 the river suggested that Great Reed Warblers preferred these to other habitats for nesting.

8 Habitat use was closely linked to the availability of reed edges and the quality of the reed stand. Overall Mayfield nest success was $43 \%$, slightly lower than in northern and western

Europe. Nest success was low along the small and large canal, where brood parasitism by Common Cuckoos (Cuculus canorus) and nest predation were high due to nearby tree lines providing perching sites to cuckoos and predators. Nest success was intermediate at the mining pond due to very high predation pressure and adverse weather, and nest success was highest in the sand pit (despite high Cuckoo parasitism) and the river (despite relatively high predation). In conclusion, our results suggest that canals can function as ecological traps, which attract edge-preferring Great Reed Warblers but are highly accessible to predators and brood parasites. In contrast, sand pits can be perceptual traps because they provide good resources for nesting but were less attractive to Great Reed Warblers than other habitats. Habitat use in relation to habitat availability thus depends primarily on the availability of reed edges and the quality of the reed stand, whereas nest success also depends on the characteristics of the surroundings and weather conditions.

Key words: brood parasitism, habitat use/availability, nest site selection, Phragmites australis, reed bed. 


\section{INTRODUCTION}

The comparison of habitat use as a function of habitat availability has been the subject of numerous studies in the past few decades (Johnson 1980, Byers et al. 1984, Santilli and Bagliacca 2010, Beyer et al. 2010). Most of the studies were implemented on mammals (Neu et al. 1974, John and Kostkan 2009), large birds (Chiang et al. 2012) and fishes (Prenda et al. 1997) using mark-recapture methods to detect the movements of individuals within and among habitat types.

The Great Reed Warbler (Acrocephalus arundinaceus), a Western Palearctic passerine species, occurs in the reed beds of slow rivers (Fischer 1991, 1994), canals (Mérö and Žuljević 2009), ponds or swamps (Mérő et al. 2014), fishponds (Dyrcz 1981, Beier, 1981, Božić 1999), but it also uses reed patches in shallow lakes (Graveland 1998, Fedorov 2000, Woithon and Schmieder 2004, Batáry and Báldi 2005, Uzun et al. 2014). The Great Reed Warbler is a reed (Phragmites australis) specialist, however, it can accidentally nest in other herbaceous vegetation as well (e.g. Dyrcz 1981, Mérő and Žuljević 2013), because reed beds occasionally contain patches of cattail (Typha sp.), sedge (Cyperaceae) and/or willow (Salix sp.). A number of studies reported that the Great Reed Warbler selects nest sites in reed adjacent to the water (Leisler 1981, Graveland 1998, Prokešová and Kocian 2004a, Prokešová and Kocian 2004b, Trnka et al. 2009) and avoids the interior of large homogeneous patches of reed. In contrast to other reed-specialist passerines, man-made habitats, such as pits, canals or waterways are highly suitable for the nesting of this species because of the high availability of reed edges (Mérő and Žuljević 2009, Mérő et al. 2014).

Here we study the nesting biology of Great Reed Warblers in five different types of reed habitat (mining pond, sand pit, large canal, small canal and small lowland river) to estimate 
nesting densities, quantify habitat use and evaluate preference for nesting habitats while also considering the proper area (excluding water surfaces) and quality of the reed beds available for nesting. Our specific aims were (1) to quantify habitat selection by comparing the use of reed habitat types in relation to their availability in an understudied region of the breeding range of this species in three years (2009-2011), (2) to estimate nest success in the five reed habitat types, and (3) to quantify the relationships between reed habitat area, the number of nests and nest success.

\section{MATERIAL AND METHODS}

Study area

The study was conducted in north-western Serbia in the province of Vojvodina, which is a typical lowland area with a semi-dry continental climate, mean annual precipitation of approximately $600 \mathrm{~mm}$ and a mean annual temperature of $10.7^{\circ} \mathrm{C}$ (Tomić 1996). We studied Great Reed Warblers in five different reed habitat types:

Bager - This former mining pond is located in the north-western outskirts of the town of

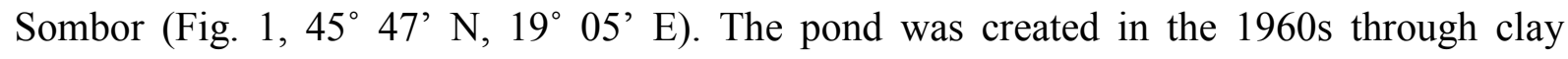
excavation for the local brickyard. The pond water level (up to $2.5 \mathrm{~m}$ ) shows large fluctuations and depends on the precipitation in autumn, in winter and in early spring and the level of groundwater. The water level decreases in the summer and early autumn due to the evapotranspiration of reed vegetation. The major vegetation cover is reed; with Lesser Bulrush (Typha angustifolia) in a small patch (covering $0.9 \%$ of the area) and some other plant species occurring sporadically (Table 1). The reed bed is scattered and is accidentally 
1 burned by locals in some years. In $2009,85 \%$ and in $2010,50 \%$ of the reed was burned at the

2 end of winter (March), while the reed was not burned in 2011. The pond is surrounded by meadows and crop fields from the north and west, and by houses from the south and east.

Pista - This reed habitat was once a sand pit, where fine-grained yellow sand was excavated in the $1970 \mathrm{~s}$ and $1980 \mathrm{~s}$ by construction companies. This habitat is located $\left(45^{\circ} 50^{\prime} \mathrm{N}, 19^{\circ} 02^{\prime}\right.$ E) in an agricultural area with fields of corn, wheat, sunflower, soya and sugar beet. The water level depends strongly on the amount of precipitation and shows large inter-seasonal fluctuations. There are some small trees on the higher banks of the pit. The pit was rapidly overgrown with reed after it had been abandoned. The pit is currently covered by a closed

reed stand, interspersed with Lesser Bulrush in several places. The reed bed was burned once in 2010 at the end of the winter.

Veliki bački canal (VBC) - We studied a section (length $900 \mathrm{~m})$ of the VBC $\left(45^{\circ} 44^{\prime} \mathrm{N}, 19^{\circ}\right.$ $10^{\prime}$ E) flowing through a typical agricultural area near the Lugovo ranches. The VBC was created between 1793 and 1801 with the main purpose of irrigation and connecting the Danube and Tisza rivers. The level of the water (originating from Danube) is stable, because it is regulated through a sluice system by the water management authority. The average width of the studied canal section is $22 \mathrm{~m}$ and depth is about $1.5 \mathrm{~m}$ near the shoreline. An approximately 2-m-wide reed bed runs on both sides, interspersed with Lesser Bulrush and other herbaceous plants and shrubs in a few places (Table 1). There is a 15-m-wide forest strip of young trees and shrubs (avg. height $10 \mathrm{~m}$ ) on both sides of the canal.

River Kígyós (Kígyós) - The Kígyós flows 37 km through north-western Vojvodina (Fig. 1). The average width is $9 \mathrm{~m}$ and depth is $1 \mathrm{~m}$ in the studied section near Kolut $(1,100 \mathrm{~m}$ long, $\left.45^{\circ} 52^{\prime} \mathrm{N}, 18^{\circ} 57^{\prime} \mathrm{E}\right)$. The stable water level depends on the water level of the VBC, because the Kígyós flows into the VBC. The reed bed on both sides is approximately $1 \mathrm{~m}$ wide with 
1 sporadic solitary shrubs (Table 1). Reed was managed by mowing in August, 2010. Wet

2 meadows and small croplands border the river on both sides.

3 Čonić - The Čonić $\left(45^{\circ} 47^{\prime} \mathrm{N}, 19^{\circ} 08^{\prime} \mathrm{E}\right)$ is a small lateral canal of the Istočna Mostonga

4 water-course (Fig. 1). The length of the studied section is $1,100 \mathrm{~m}$ with an average width of 3

$5 \mathrm{~m}$, and depth of $0.8 \mathrm{~m}$. The level of the water rarely shows minor fluctuations. This lateral

6 canal has a drainage and irrigation function. There is a $0.5-\mathrm{m}$-wide reed stand interspersed

7 with Common Bulrush (Typha latifolia) in some places on both banks. The reed bed was

Field sampling and statistical analysis

Nests were surveyed with a similar intensity and effort during the entire nesting season at each study site from May to August 2009-2011 (Table 1). We measured the area of the entire reed habitat and the exact area covered by reed in GIS, constructed from field measurements obtained by hand-held GPS receivers at each location. Along the linear reed habitat types (VBC, Kígyós and Čonić), we surveyed sections along the canals and river length where reed was dominant and for which endpoints could be easily identified in the field (e.g. between two bridges). The length and width of the linear habitats were also measured by GPS. In the standing waters of Bager and Pista, the entire reed bed was systematically surveyed for Great Reed Warbler nests. In linear reed habitats, nests were searched on both sides by walking through the reed bed (VBC, Kígyós) or by walking in the water searching the reed edge (Čonić). We visited all sites at least twice a week and attempted to find all Great Reed 
1 Warbler nests at the sites. The possibility that a nest escaped our attention was small because

2 Great Reed Warblers are territorial and most birds seen during subsequent checks could be matched to a nest. The nests found were regularly checked once every five days, when we recorded the number of eggs, the number of nestlings, the loss of eggs or nestlings, and parasitism by Cuckoos (Cuculus canorus). We also recorded the fate of the nests using three categories: successful with Great Reed Warbler fledglings, unsuccessful due to Cuckoo parasitism and unsuccessful due to predation or abandonment.

In analysis, we first estimated nest success based on the egg and nestling data. We defined nest success as the probability that an egg produces a fledgling. To estimate nest success, we applied the Mayfield method (Mayfield 1975) as improved by Johnson (1979) and Hensler and Nichols (1981). The multiplication of the egg and nestling survival rate (two Mayfield estimates) for the entire incubation and nestling period and the hatching rate resulted the final nest success rate, which was converted to percentages. We applied the J-test, which compares two Mayfield survival rates (Johnson 1979, see http://www.biol.uni.wroc.pl/halupka) to check differences in egg and nestling survival rates among reed habitat types. To test differences in nesting success among the five reed habitat types, we grouped them in two waysbased on: (1) their spatial arrangement and water level fluctuation: linear water habitats (i.e., canals characterized by stable water level) and more two-dimensional habitats (i.e., impoundments where fluctuation in water level was high), and (2) the presence or absence of wood vegetation on banks. We then used Student's t-test to compare the breeding success variables. Second, we calculated the proportion of nests parasitized by Cuckoos and the proportion of nests lost (both abandoned and depredated broods) for each reed habitat type relative to the total number of nests. Third, the number of nests found in each reed habitat type (i.e., use of reed habitat types) was compared to the expected number of nests based on either the area of 
1 the study sites, the area of the reed bed or the area of reed cover (i.e., three measures of

2 habitat availability) using chi-square tests (Byres et al. 1984). The expected number of nests was estimated based on the logic that if habitat use is random, the number of nests in each site should be proportional to the area or the reed area of the site. We thus calculated the proportion of area for each site (e.g. area of Bager/total area of five sites) and multiplied this by the total number of nests found in the five sites $(n=174)$. The same calculation was used for the area of reed bed at the sites and for the area actually covered by reed. The latter two variables were different because reed beds could contain other plant species as well. Nevertheless, all nests were found in reed. Finally, we tested whether the number of nests and nest success per site were related to the area of the reed bed using Spearman rank correlation. Statistical analyses were performed in the SPSS for Windows 17.0 statistical software.

\section{RESULTS}

We found a total of 174 Great Reed Warbler nests, all in reed. The nests were built up to 1 $\mathrm{m}$ from the reed edge adjacent to water in linear reed habitats (VBC, Kígyós and Čonić), while up to $5 \mathrm{~m}$ from the edge at Bager. However, all nests at Pista and half of the nests at Bager were found in reed edges adjacent to the shoreline. The number of nests was higher than expected based on the area of the study sites at Bager, Kígyós and Čonić, and was lower than expected at Pista and VBC (Fig. 2, $\chi_{4}^{2}=37.118, P<0.0001$ ). However, when the expected number of nests was based on the area of the reed bed, the number of observed nests was lower than the expected number at Bager and Pista, was similar to the expected number at VBC and was higher than expected at Kígyós and Čonić (Fig. $2, \chi_{4}^{2}=126.670, P<0.0001$ ). The same pattern of expected nests were observed when habitat availability was conducted 
1 based on the area of the reed cover (Fig. 2, $\chi_{4}^{2}=135.074, P<0.0001$ ). There was no

2 relationship between the number of nests and either the area of the study site (Spearman rank

3 correlation, $\left.r_{s}=0.6, P=0.23\right)$, the area of the reed bed $\left(r_{s}=0.3, P=0.52\right)$ or the area of the

$4 \quad$ reed cover $\left(r_{s}=0.3, P=0.68\right)$.

The overall nesting success for the two study years and five reed habitat types exhibited $43 \%(n=174)$, with an average of 3.8 successfully fledged young. Clutch survival rate was higher than nestling survival rate at Bager, VBC and Kígyós (Table 2). We found no differences in the nesting success between the linear water habitats and the impoundments (Student's t-test, $\mathrm{t}_{1}=1.80, P=0.323$ ) or the between the reed habitat types with and without trees on banks $\left(\mathrm{t}_{1}=0.21, P=0.870\right)$. The highest rate of Cuckoo parasitism occurred where trees, i.e., potential Cuckoo perching sites were near the reed beds (Pista, VBC, Čonić; Tables 1 and 2). The rate of nest loss (depredated and abandoned) ranged between 0.33 and 0.53 , except for Pista, where no nest loss occurred (Table 2). There was no significant relationship between nest success and the area of the study site $\left(r_{s}=-0.2, P=0.78\right)$ or the area of the reed bed $\left(r_{s}=0.4, P=0.52\right) \mathrm{XX}$.

\section{DISCUSSION}

Our comparisons of observed nest numbers versus numbers expected based on the area of available habitat found significant deviations from the null hypothesis of no preference among the study sites. The Kígyós and Čonić were used by higher numbers of Great Reed Warblers than expected, whereas there were fewer nests than expected at Pista. The use of Bager and VBC depended on whether the entire site area, or only the area of the reed bed, or the area of the reed cover was considered in the available habitat. This is not surprising if one considers 
that Bager had the largest reed bed area (1.2 ha) and the largest proportion of area actually covered by reed of the five sites and VBC had one of the lowest proportion (20\%) of reed bed area relative to total site area. These conditions led to two very different estimates for the expected number of nests (Fig. 2). However, these contrasting results also draw attention to the importance of using spatially explicit criteria for determining the area for which nesting density is calculated. Such differences in the delineation of habitat patches may contribute to the wide variation in nesting density reported in many previous studies.

Although this species builds its nests at the reed edge adjacent to the water (Báldi 1999, Báldi and Kisbenedek 1999, Prokešová and Kocian 2004b, Báldi and Batáry 2005, Trnka et al. 2009, Trnka and Prokop 2010), in reed habitats without water surface, i.e. closed reed stand (Pista, Table 1) or with very small water surface (Bager, Table 1) Great Reed Warblers raise their broods in the reed edge adjacent to the banks (Mérö et al. 2014). Beside the edges, reed stem density and reed stem diameter significantly affect nest site selection (Mérő and Žuljević 2014). The lower nesting density of Great Reed Warbler at Pista might thus be a consequence of the avoidance of those parts of the reed bed, which were interspersed with Lesser Bulrush. The positive preference of reed edges suggests a reasonable explanation for why nesting densities in the linear habitats were higher, although reed beds were narrow (except for the VBC). The strong preference of edges and pure reed stands of the species seemed more important than the area of the reed beds.

Overall nest success found in our study was similar to that found in central Hungary, where it was estimated at 35\% (Batáry and Báldi 2005). However, nest success recorded in more northern and northwestern European regions was higher, ranging between 44 and 56\% (Beier 1981, Leisler et al. 1995, Petro et al. 1998, Božić 1999). Our results suggest that nest success was rather consistent in various reed habitat types. However, we found no difference in 
nesting success between the reed habitats classified based on their form, i.e. linear reed habitats vs. impoundments. Our results were comparable with previous ones in the general study region. For example, Mérő et al. (2014) reported 43\% nest success in a mining pond, which was similar to Bager in this study, where overall nest success was $44 \%$. The extremely low nest success at Bager in 2010 was a consequence of the rapid water level increase caused by the large amount of precipitation (Mérő et al. 2014). Nest success on the VBC and Čonić ranged from 0 to $23 \%$ because of the high rate of Cuckoo parasitism (Mérő and Žuljević 2009, Mérő et al. 2013), which was confirmed here as well (overall nest success 23\%). These results indicate that Cuckoo parasitism is high where perches (e.g. shrubs, solitary trees, forest belts, electric wires etc.) border the reed bed (Tables 1 and 2; see also Moskát and Honza 2000, Mérő et al. 2013).

Beyond the availability and distance of Cuckoo perches directly related to Cuckoo nest parasitism (discussed above), other important factors governing nest success were nest predation and abandonment. The presence of water in the reed bed, the shape of the reed bed and the potential perches could influence predation pressure (Hansson et al 2000a, 2000b). Moreover, nests in reed beds in narrow strips bordered by land (e.g. along large and small canals) were also exposed to mammalian predators. In order to minimize the possibility of Cuckoo parasitism, Great Reed Warblers at times abandon nests in egg laying stage (Moskát and Honza 2002, Moskát 2005, Trnka and Grim 2014, Moskát et al. 2014). Nest predation and abandonment was common in sites with high rates of Cuckoo parasitism (VBC and Čnić) but was surprisingly absent in another site with high parasitism rate (Pista). On the other hand, Cuckoo parasitism was low or non-existent at Bager pond and Kígyós River, where environmental factors and predation pressure were primarily responsible for nest loss. Stormy wind followed by extended rainfall, decreased air temperatures, can damage the nests 
or the nest supporting reed stems, or the eggs and the nestlings are able to cool down, or even govern the course of the entire breeding season (Bensch and Hasselquist 1994, Schaefer et al. 2006, Dyrcz and Halupka 2009, Honza et al. 2012, Mérő et al. 2013, Mérő et al. 2014).

There were several interesting patterns in habitat use and nest success that require attention. First, canals (VBC and Čonić) had the lowest nest success overall and in most years even though they were often used for nesting. These canals, with artificial hydro-morphology and long narrow strips of reed often bordered by trees can be attractive to Great Reed Warblers, which prefer reed edges, but can suffer from increased Cuckoo parasitism and high predation pressure. In contrast, Pista, a sand mining pond, was not as attractive to Great Reed Warblers as expected (lower use relative to availability) but provided quite stable conditions for nesting and brood-rearing (highest overall nest success despite high Cuckoo parasitism rate). The Bager similarly had lower use than expected (based on area of reed bed) and low Cuckoo parasitism but likely higher predation pressure, which resulted in a slightly lower overall nest success than in Pista. Finally, Kígyós with highest proportion of the reed cover among the linear habitats provides attractive nesting habitat (higher use than expected based on reed bed area) and low Cuckoo parasitism but higher predation pressure, which also resulted in a slightly lower overall nest success than in Pista. The different patterns may be explained if the sites are occupied by Great Reed Warblers of different body condition, age or experience, however further studies using individual marking are required to help refute or corroborate these possibilities.

In conclusion, we found that nest success was lower in this study than in the northern and north-western regions of Europe. However, we suggest that these differences within the nesting range of the Great Reed Warbler arise from different reed habitat types (i.e. ponds, pits and linear reed habitats in this study; fish ponds and lakes in other studies) and may not 
1

reflect geographical gradients. In the aspect of habitat use/availability we found that nest site selection was independent from the area of the reed bed; while the quality of the reed stand and availability of the reed edges seemed to play a more important role. Besides, nest success also varied among the different reed habitat types, however this variation also was independent of the area of the reed bed.

\section{ACKNOWLEDGEMENTS}

The fieldwork was supported by the Nature Protection and Study Society - NATURA, Sombor. Thomas Oliver Mérő, Katalin Varga and Szabolcs Lengyel were supported by three grants from the Hungarian Scientific Research Fund - Norway Financing Mechanism (OTKA NNF 78887, 85562, K 106133) during manuscript preparation.

\section{LITERATURE CITED}

BATÁRY, P. AND A. BÁLDI. 2005. Factors affecting the survival of real and artificial great reed warbler's nests. Biologia 60:215-219.

BÁLDI, A. 1999. Microclimate and vegetation edge effects in a reedbed in Hungary. Biodiversity and Conservation 8:1697-1706.

BÁLdi, A. AND T. KisBenEDEK. 1999. Species-specific distribution of reed-nesting passerine birds across red-bed edges: effect of spatial scale and edge type. Acta Zoologica Academiae Scientiarum Hungaricae 45:97-114.

BÁLDI, A. AND P. BATÁRY. 2005. Nest predation in European reedbeds: different losses in edges but similar losses in interiors. Folia Zoologica 54:285-292. 
1 BEIER, J. 1981. Untersuchungen an Drossel- und Teichrohrsänger (Acrocephalus arundinaceus, A. scirpaceus): Bestandsentwicklung, Brutbiologie, Ökologie. In German. Journal of Ornithology 122:209-230.

Bensch, S. AND D. Hasselquist. 1994. Higher rate of nest loss among primary than secondary females: infanticide in the great reed warbler? Behavioral Ecology and Sociobiology 35:309-317.

Beyer, H. L., D. T. Haydon, J. M. Morales, J. L. Frair, M. Hebblewhite, M. Mitchell, AND J. MATTHIOPOULOS. 2010. The interpretation of habitat preference metrics under use-availability designs. Philosophical Transactions of the Royal Society B $365: 2245-2254$.

BožIĆ, A. I. 1999. Breeding biology of the Great Reed Warbler Acrocephalus arundinaceus at Draga fish-ponds near Ig (Ljubljansko barje, Slovenija). Acrocephalus 20: 177-188.

Byers, R. C., K. R. Steinhorst, AND R. P. KRAUSMAN. 1984. Clarification of a technique for analysis of utilization-availability data. The Journal of Wildlife Management 48:1050-1053.

Chiang, S. N., P. H. Bloom, A. M. Bartuszevige, and S. E. Thomas. 2012. Home range and habitat use of Cooper's Hawk in urban and natural areas. Online www.ucpress.edu/go/sab in Urban bird ecology and conservation (C. A. Lepczyk, and P. S. Warren, Editors). University of California Press, Berkeley, California, USA.

DYRCZ, A. 1981. Breeding ecology of great reed warbler Acrocephalus arundinaceus and reed warbler Acrocephalus scirpaceus at fish-ponds in SW Poland and lakes in NW Switzerland. Acta Ornithologica 18:307-334. 
Dyrcz, A. AND L. HalupKA. 2009. The response of Great Reed Warbler Acrocephalus arundinaceus to climate change. Journal of Ornithology 150:39-44.

Fedorov, V. A. 2000. Breeding biology of Great Reed Warbler Acrocephalus arundinaceus in the southwest of Pskov region. Avian Ecology and Behaviour 5:63-77.

FISCHER, S. 1991. Gelegegrösse des Drosselrohrsänger Acrocephalus arundinaceus an Berliner Seen. In German. Vogelwelt 112:236-242.

FISCHER, S. 1994. Einfluss der Witterung auf den Bruterfolg des Drosselrohrsängers Acrocephalus arundinaceus am Berliner Müggelsee. In German. Vogelwelt 115:287-292.

GRAVELAND, J. 1998. Reed die-back, water level management and the decline of the Great Reed Warbler Acrocephalus arundinaceus in The Netherlands. Ardea 86:187-201.

Hansson, B., S. Bensch AND D. HASSElquist. 2000a. Patterns of nest predation contribute to polygyny in the Great Reed Warbler. Ecology 81:319-328.

Hansson, B., B. Staffan AND D. Hasselquist. 2000. The quality and the timing hypotheses evaluated using data on great reed warblers. Oikos 90:575-581.

Hensler, G. L. AND J. D. Nichols. 1981. The Mayfield method for estimating nesting success: a model, estimators and simulation results. Wilson Bulletin 93:42-53.

Honza, M., P. ProcházKa AND M. PožGayovÁ. 2012. Do weather conditions affect the colouration of great reed warbler Acrocephalus arundinaceus eggs? Folia Zoologica 61:219-224.

John, F. And V. KostKan. 2009. Compositional analysis and GPS/GIS study of habitat selection by the European beaver, Castor fiber in the middle reaches of the Morava River. Foolia Zoologica 58:76-86. 
JoHnSON, D. H. 1979. Estimating nest success: the Mayfield method and an alternative. The Auk 96:651-661.

JoHnSON, D. H. 1980. The comparison of usage and availability measurements for evaluating resource reference. Ecology 61:65-71.

LEISLER, B. 1981. Die ökologische Einmischung der mitteleuropäischen Rohrsänger (Acrocephalus, Sylviinae). I. Habitattränung. In German. Vogelwarte 31:45-74.

Leisler, B., J. Beier, G. Heine, And K-H. Siebenrock. 1995. Age and other factors influencing mating status in German Great Reed Warblers (Acrocephalus arundinaceus). Japanese Journal of Ornithology 44:169-180.

MAYFIELD, H. 1975. Suggestions for calculating nest success. Wilson Bulletin 87: 456-466.

MÉRÖ, T. O. AND A. ŽUlJEVIĆ 2009. Breeding density and breeding success of the Great Reed Warbler Acrocephalus arundinaceus in Sombor municipality. In Serbian. Ciconia 18:91-98.

MÉRÖ, T. O. AND A. ŽulJević. 2013. Great Reed Warbler Acrocephalus arundinaceus. Acrocephalus 34:129-130.

MÉRÖ, T. O., A. ŽUlJEVIĆ, K. VARGA, AND S. LENGYEL. 2013. Breeding of the brood parasitic Common Cuckoo (Cuculus canorus) in reed habitats in NW Vojvodina, Serbia. Natura Croatica 22:265-273.

MÉRÖ, T. O. AND A. ŽULJEVIĆ. 2014. Effect of reed quality on the breeding success of the Great Reed Warbler Acrocephalus arundinaceus. Acta Zoologica Bulgarica 66:511516.

MÉRÖ, T. O., A. ŽulJević, K. VARGA, R. BOCZ, AND S. LENGYEL. 2014. Effect of reed burning and precipitation on the breeding success of Great Reed Warbler, Acrocephalus arundinaceus, on a mining pond. Turkish Journal of Zoology 38:622-630. 
MoskÁt, C. AND M. HonZA. 2000. Effect of nest and nest site characteristics on the risk of Cuckoo Cuculus canorus parasitism in the Great Reed Warbler Acrocephalus arundinaceus. Ecography 23:335-341.

MoskÁt, C. AND M. HonZA. 2002. European Cuckoo Cuculus canorus parasitism and host's rejection behaviour in a heavily parasitized Great Reed Warbler Acrocephalus arundinaceus population. Ibis 144:614-622.

MoskÁt, C. 2005. Nest defence and egg rejection in great reed warbler over the breeding cycle: are they synchronised with the risk of brood parasitism. Annales Zoologici Fennici 42:579-586.

Moskát, C., M. E. Hauber, Z. Elek, M. Gommers, M. Bán, F. Groenewoud, T. S. L. Versluijs, C. W. A. Hoetz AND J. Komdeur. 2014. Foreign egg retention by avian hosts in repeated brood parasitism: why do rejecters accept? Behavioral Ecology and Sociobiology 68:403-413.

Neu, C. W., R. C. Byers, AND J. M. PeEK. 1974. A technique for analysis of utilizationavailability data. The Journal of Wildlife Management 38:541-545.

Petro, R., I. LiterÁK, AND M. HonZA. 1998. Breeding biology and migration of the great reed warbler Acrocephalus arundinaceus in the Czech Silesia. Biologia 53: 685-694.

Prenda, J., P. D. Armitage, And A. Grayston. 1997. Habitat use by the fish assemblages of two chalk streams. Journal of Fish Biology 51:64-79.

ProkeŠOVÁ, J. AND L. Kocian. 2004a. Habitat selection of two Acrocephalus warblers breeding in reed beds near Malacky (Western Slovakia). Biologia 59:637-644.

ProkešovÁ, J. AND L. Kocian. 2004b. Distribution of nests of great reed warbler (Acrocephalus arundinaceus) and reed warbler (Acrocephalus scirpaceus) in reed beds near Malacky (Western Slovakia). Tichodroma 16:36-47. 
1 Santilli, F. AND M. Bagliacca. 2010. Habitat use by the European Wild Rabbit (Oryctolagus cuniculus) in a coastal sandy dune ecosystem of Central Italy. Hystrix The Italian Journal of Mammology 21:57-64.

Schaefer, T., G. Ledebur, J. Beier AND B. Leisler. 2006. Reproductive responses of two related coexisting songbird species to environmental changes: global warming, competition, and population sizes. Journal of Ornithology 147:47-56.

SurmacKI, A. 2004. Habitat use by Reed Bunting Emberiza schoeniclus in an intensively used farmland in Western Poland. Ornis Fennica 81:137-143.

Tomić, P. 1996. Klima. Pages 16-21 in Opština Sombor (J. Đuričić, Editor). Prirodno matematički fakultet, Institut za geografiju and Prosveta, Novi Sad.

TRNKA, A., P. BATÁRY, AND P. Prokop. 2009. Interacting effects of vegetation structure and breeding patterns on the survival of Great Reed Warbler Acrocephalus arundinaceus nests. Ardea 97:109-116.

TRNKA, A. AND P. PROKOP. 2010. Does social mating system influence nest defence behaviour in Great Reed Warbler (Acrocephalus arundinaceus) males? Ethology 116:10751083.

TRNKA, A. AND T. GRIM. 2014. Testing for correlations between behaviours in a cuckoo host: why do host defences not covary? Animal Behaviour 92:185-193.

Uzun, A., Z. Ayyildiz, F. Yilmaz, B. UzUn, AND M. SAĞIROĞLU. 2014. Breeding ecology and behavior of the Great Reed Warbler, Acrocephalus arundinaceus, in Poyrazlar Lake, Tureky. Turkish Journal of Zoology 38:55-60.

Woithon, A. AND K. Schmieder. 2004. Bruthabitatmodellierung für den Drosselrohrsänger (Acrocephalus arundinaceus $\quad$ L.) als Bestandteil eines integrativen Managementsystems für Seeufer. Limnologica 34:132-139. 
1 TABLE 1. Main characteristics of the studied reed habitats.

\begin{tabular}{|c|c|c|c|c|c|c|c|}
\hline \multirow[b]{2}{*}{ Study area } & \multirow{2}{*}{$\begin{array}{l}\text { Total } \\
\text { area } \\
(\text { ha) }\end{array}$} & \multirow{2}{*}{$\begin{array}{l}\text { Reed } \\
\text { bed } \\
\text { (ha) }\end{array}$} & \multirow{2}{*}{$\begin{array}{c}\text { Distance of } \\
\text { potential } \\
\text { Cuckoo } \\
\text { perches }(\mathrm{m})\end{array}$} & \multicolumn{4}{|c|}{ Vegetation cover of reed beds (\%) } \\
\hline & & & & $\begin{array}{c}\text { Phragmites } \\
\text { australis }\end{array}$ & Typha sp. & $\begin{array}{l}\text { Other } \\
\text { plants }\end{array}$ & Woody \\
\hline Bager & 1.3 & 1.2 & 30 & 90 & 9 & 1 & 0 \\
\hline Pista & 0.7 & 0.7 & 10 & 60 & 30 & 10 & 0 \\
\hline VBC & 2.0 & 0.4 & 0 & 80 & 15 & 4 & 1 \\
\hline Kígyós & 1.0 & 0.2 & 5 & 90 & 0 & 9 & 1 \\
\hline Čonić & 0.4 & 0.1 & 10 & 60 & 5 & 34 & 1 \\
\hline
\end{tabular}

$2{ }^{\mathrm{a}}$ area of the entire reed habitat; ${ }^{\mathrm{b}}$ area of reed habitat without open water surfaces

3 
1 TABLE 3. Breeding parameters and success of Great Reed Warblers in five reed habitats in

$2 \quad 2009-2011$.

\begin{tabular}{llllll}
\hline \multicolumn{1}{c}{ Breeding parameters } & Bager & Pista & VBC & Kígyós & Čonić \\
\hline Clutch survival rate & 0.64 & 0.75 & 0.41 & 0.64 & 0.46 \\
Chick survival rate & 0.73 & 0.79 & 0.62 & 0.82 & 0.56 \\
z & 2.01 & 0.51 & 2.22 & 3.03 & 0.96 \\
$P^{\text {b }}$ & 0.044 & 0.61 & 0.026 & 0.002 & 0.33 \\
Rate of Cuckoo & 0.00 & 0.35 & 0.34 & 0.02 & 0.42 \\
parasitized nests & & & & & 0.33 \\
Rate of abandoned & 0.53 & 0.00 & 0.41 & 0.41 & 23 \\
and depredated nests & 67 & 53 & 0 & 42 & 1 \\
$\begin{array}{l}\text { Nest 2009 } \\
\text { success 2010 }\end{array}$ & 18 & 66 & 42 & 35 & 29 \\
$\begin{array}{l}\text { \%) 2011 } \\
\text { Overall nest success }\end{array}$ & $\mathbf{4 4}$ & 46 & 19 & 76 & $\mathbf{2 3}$ \\
$\mathbf{( \% )}$ & $\mathbf{5 5}$ & $\mathbf{2 3}$ & $\mathbf{4 9}$ & \\
\hline
\end{tabular}

$3 \frac{(\%)}{{ }^{a} \text { days since April } 1 \text { in each study year; }{ }^{b} \text { the level of significance obtained by J-tests comparing clutch and }}$ nestling survival; 
1 TABLE 2. Number and density of Great Reed Warbler nests at each study site.

\begin{tabular}{lcccccccc}
\hline \multirow{2}{*}{ Study area } & \multicolumn{4}{c}{ Number of nests } & \multicolumn{5}{c}{ Nest density per reed habitat $\left(\mathrm{ha}^{-1}\right)$} \\
\cline { 2 - 9 } & 2009 & 2010 & 2011 & Average & 2009 & 2010 & 2011 & Average \\
\hline Bager & 11 & 29 & 20 & 16.7 & 8.5 & 22.3 & 15.4 & 12.8 \\
Pista & 5 & 6 & 6 & 5.7 & 7.1 & 8.6 & 8.6 & 8.1 \\
VBC & 10 & 11 & 11 & 10.7 & 5.1 & 5.6 & 5.6 & 5.4 \\
Kígyós & 5 & 21 & 15 & 13.7 & 5.1 & 21.2 & 15.2 & 13.8 \\
Čonić & 9 & 5 & 10 & 8.0 & 20.4 & 11.4 & 22.7 & 18.2 \\
\hline
\end{tabular}

2 
1 FIG. 1. Location of the study sites in north-western Vojvodina (Serbia).

2

3 FIG. 2. The number of nests observed and expected based on the area of study sites (Expected

$4 \quad 1$, gray bars) and based on the area of the reed bed (Expected 2, white bars).

5 
1 FIG. 1.

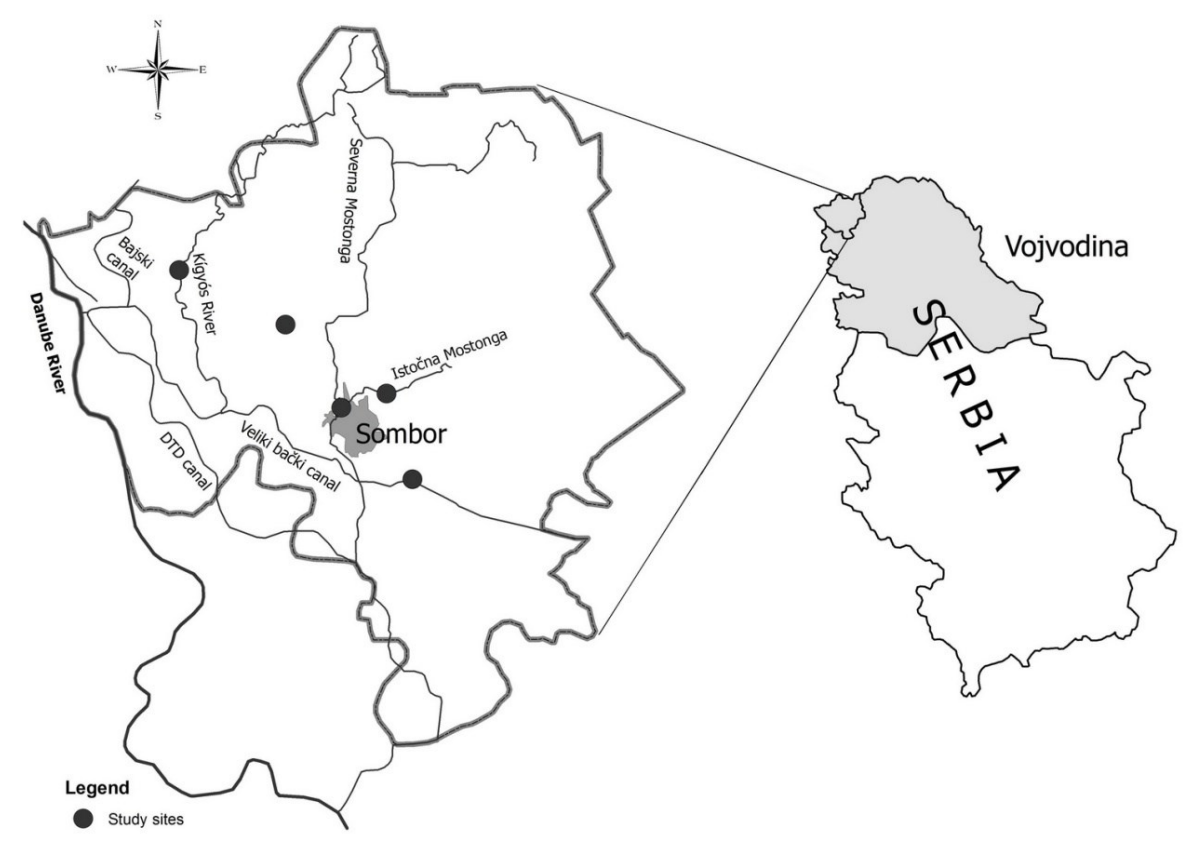


1 FIG. 2.

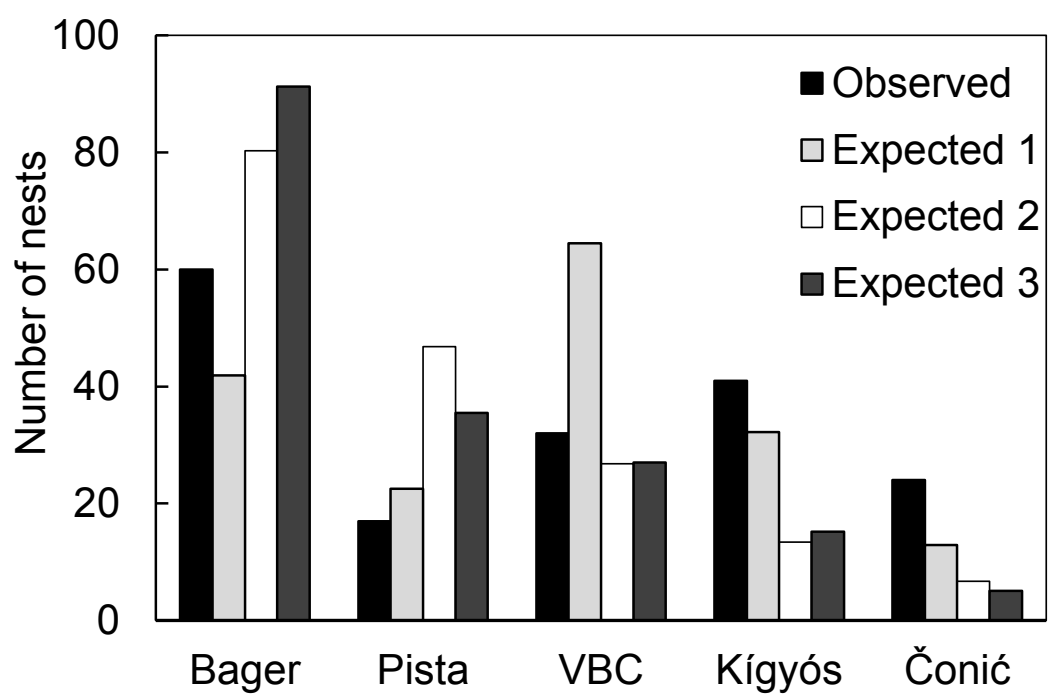

2 